\title{
Essay
}

\section{Moving beyond GK-12}

\section{J. A. Ufnar, ${ }^{* \dagger}$ Susan Kuner, ${ }^{\ddagger}$ and V. L. Shepherd ${ }^{\dagger \S \|}$}

\begin{abstract}
${ }^{*}$ Division of Science and Technology, Southern Vermont College, Bennington, VT 05201; ${ }^{\dagger}$ Center for Science Outreach, Vanderbilt University, Nashville, TN 37240; †Topaz Canyon Group, Alameda, CA 94501; § Department of Veterans Affairs, Nashville, TN 37212; "Department of Pathology, Microbiology and Immunology, Vanderbilt University, Nashville, TN 37232
\end{abstract}

Submitted December 29, 2011; Revised March 21, 2012; Accepted April 9, 2012

Monitoring Editor: Nancy Moreno

\begin{abstract}
The National Science Foundation GK-12 program has made more than 300 awards to universities, supported thousands of graduate student trainees, and impacted thousands of K-12 students and teachers. The goals of the current study were to determine the number of sustained GK-12 programs that follow the original GK-12 structure of placing graduate students into classrooms and to propose models for universities with current funding or universities interested in starting a program. Results from surveys, literature reviews, and Internet searches of programs funded between 1999 and 2008 indicated that 19 of 188 funded sites had sustained in-classroom programs. Three distinct models emerged from an analysis of these programs: a full-stipend model, in which graduate fellows worked with partner teachers in a K-12 classroom for $2 \mathrm{~d} / \mathrm{wk}$; a supplemental stipend model in which fellows worked with teachers for $1 \mathrm{~d} / \mathrm{wk}$; and a service-learning model, in which in-classroom activity was integrated into university academic coursework. Based on these results, potential models for sustainability and replication are suggested, including establishment of formal collaborations between sustained GK-12 programs and universities interested in starting in-classroom programs; development of a new Teaching Experience for Fellows program; and integration of supplemental fellow stipends into grant broader-impact sections.
\end{abstract}

\section{INTRODUCTION}

In early 2011, the National Science Foundation (NSF) unexpectedly announced the end of the highly regarded and very popular GK-12 program (Mervis, 2011). The program made more than 300 awards to universities throughout the United States, supported thousands of graduate student trainees, and impacted tens of thousands of $\mathrm{K}-12$ students and thousands of K-12 teachers (Gamse et al., 2010). According to recent reports, the NSF GK-12 program "has achieved its goal of providing models for potential adopters; recent evaluation

DOI: $10.1187 /$ cbe.11-12-0119

Address correspondence to: V. L. Shepherd (virginia.l.shepherd@ vanderbilt.edu).

(C) 2012 J. A. Ufnar et al. CBE-Life Sciences Education (C) 2012 The American Society for Cell Biology. This article is distributed by The American Society for Cell Biology under license from the author(s). It is available to the public under an AttributionNoncommercial-Share Alike 3.0 Unported Creative Commons License (http:/ / creativecommons.org/licenses/by-nc-sa/3.0).

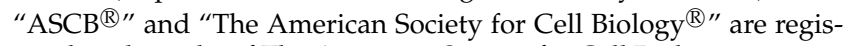
tered trademarks of The American Society for Cell Biology. findings suggest that the effects of this program's fellowship experience in improving the trainees' research skills are mixed; and the program design limits the ability of participants to gain enough in-depth experience in $\mathrm{K}-12$ teaching to impact pupil learning" (American Institute of Physics, 2011). The challenges now for past and current GK-12-funded universities and program directors are to determine which aspects of the programs can and should be sustained, what sustainable GK-12 models exist that could be adapted by any university, and how the activities deemed as essential and beneficial to all participants can be continued. More importantly, participants in this program need to disseminate findings and propose sustainable models that can now be adopted by other universities. The key question that must be addressed is whether there is a place for a program similar to the GK-12 on university campuses, and if so, what this model looks like and what the requirements are for sustainability.

The GK-12 program was originally designed to connect graduate and advanced undergraduate students (fellows) in the science, technology, engineering, and mathematics (STEM) disciplines with K-12 classroom teachers and students (Mervis, 1999; Lundmark, 2004). As stated in the most recent GK-12 program announcement, anticipated outcomes 
include improved communication, teaching, collaboration, and team-building skills for the fellows; professional development opportunities for $\mathrm{K}-12$ teachers; enriched learning for K-12 students; and strengthened and sustained partnerships in STEM between institutions of higher education and local school districts (NSF, 2009).

Reports from a variety of university GK-12 programs have indicated that their specific programs fulfilled many of these expected outcomes. Fellows have gained important mentoring and teaching skills, as well as an understanding of the needs of $\mathrm{K}-12$ teachers and classrooms (Thompson et al., 2002a; Stamp and O'Brien, 2005; Trautmann, 2008). Fellows have reported that these skills have assisted them not only in their future careers, but in securing their first academic teaching position (Trautmann and Krasny, 2006). Fellows have also gained an important understanding of the responsibility of research scientists to "give back to their community." Although recent reports state that there has been limited impact on student learning, several universities have shown that placing fellows in K-12 science classrooms has had positive impacts on the achievement of students as measured by pre/post and/or standardized tests (Spillane, 2004; Williamson et al., 2005; Smith et al., 2009; Gamse et al., 2010). In addition, as reported in the recent GK-12 evaluation study conducted by Abt Associates, more than $90 \%$ of surveyed teachers reported a positive impact on student knowledge of math and science, as well as an increased interest in and excitement about science (Gamse et al., 2010). More important gains or impacts may be in the intangible effects on students, in which fellows serve as important role models for students and encourage them to continue STEM studies (Bledsoe et al., 2004). With respect to teachers, many projects reported that teachers gained from the "partnership-building" summer workshops, learned new science concepts from their partner fellows during their in-classroom team teaching, and gained confidence in integrating inquiry-based lessons more frequently in their curriculum (Thompson et al., 2002b; Cormas and Barufaldi, 2011). In the Abt study, $84 \%$ of teachers surveyed stated that they were more likely to use hands-on teaching in their classrooms, and $65 \%$ reported that they were more confident in using this approach to teach science (Gamse et al., 2010). At the university level, faculty reported that partnerships with the local school districts were strengthened, and administrators, faculty, and students demonstrated increased enthusiasm for participating in partnership activities with $\mathrm{K}-12$ teachers and students. Importantly, it was shown that the program did not lead to increased time to graduation for fellows, that benefits outweighed the time required of the fellows, and that the program had an overall positive effect on the fellows' training and preparation (Gamse et al., 2010; Thompson et al., 2002a; Trautmann, 2008).

In the current paper, results are presented of an extensive survey of GK-12 programs funded from 1999 to 2008, with a goal of discussing sustained program models that have emerged from past and ongoing programs that could be replicated and sustained on university campuses.

\section{METHODS}

For this study, data were collected using three primary methods. First, a list was created of all programs using the NSF website (www.nsf.gov), the American Association for the Advancement of Science (AAAS) GK-12 locator site (AAAS, 2011), and an Internet search of individual program websites. Information collected included principal investigator (PI) and program coordinator contacts, lead university, email addresses, websites (if available), years participated, total number of program years, and whether the institution was public or private. Second, an email survey was sent to the PI or program coordinator of current and completed GK-12 programs asking for a response to two questions: 1) Has any aspect of your GK-12 program been or will be continued after termination of the NSF funding? If so, could you send a brief description of those activities, and where the funding for continuation has come from? 2) If activities have not continued, would you send a brief reply stating this and reasons for discontinuation? Third, an exhaustive search was conducted of the Internet, peer-reviewed literature, and information from GK-12 websites. Using these data, a table was compiled of the information for the approximately 188 former and current GK-12 programs. This table and the data can be accessed from the Vanderbilt Center for Science Outreach website (www.scienceoutreach.org). The following results reflect the data recovered from these methods and include all programs that have been funded through 2008. Grants that were considered short term (i.e., less than 3 yr) and grants to organizations such as the AAAS or the American Physiological Society were omitted from this study. In some cases, no program information was available; this is noted in the table, and these projects were considered "not sustained."

\section{RESULTS}

\section{General Features of GK-12 Programs: 1999-2008}

The focus of the current study was to collect data from GK12 programs funded from 1999 to 2008 , with a goal of determining in-classroom models that had been continued or for which plans had been developed to continue beyond NSF funding. Most of the analysis was done on 3-, 6-, and 8-yr awards during the first $6 \mathrm{yr}$ of the program, since the 5-yr awards (2007-2010) were too recent to have attained sustainability by the time of the data collection. The results in Table 1 show the breakdown in the number of grants per year and the number of years of funding per number of grants. During the years analyzed in the current paper (2000-2008) a total of 188 individual universities were funded, with an additional 60 renewals for a total of 248 awards. The program structure changed three times during 2000-2008. From 1999 to 2002, PIs could apply for 3-yr awards with the possibility of one 3-yr renewal. In 2003, Track II awards were initiated, allowing universities to apply for an initial Track I 3-yr grant with competitive renewals (Track II) for an additional $5 \mathrm{yr}$. In 2007, the program was changed to a single submission of 5 yr with no possibility for renewal. Projects eligible in 2007 for Track II awards were allowed to submit one-time-only 3-yr Track II renewals (for a total of $6 \mathrm{yr}$ ). The largest number of grants awarded were for 3 yr $(87 ; 47 \%)$, with 41 5-yr, 19 6-yr, and 418 -yr awards. There were 95 email responses to the survey, for a response rate of $51 \%$. The highest percentage of responses was 79\% (15/19) of 6-yr grant recipients, $66 \%$ of 8 -yr awardees, $37 \%$ of 5 -yr grants, and $44 \%$ of $3-y r$ grants. Responses were spread throughout the funding period, with 
Table 1. Summary of GK-12 program funding models: 1999-2008

\begin{tabular}{|c|c|c|c|c|c|c|c|c|}
\hline \multirow[b]{2}{*}{ Start year } & \multirow[b]{2}{*}{ Grant type } & \multirow{2}{*}{$\begin{array}{l}\text { Number of } \\
\text { new awards }\end{array}$} & \multirow{2}{*}{$\begin{array}{c}\text { Total number } \\
\text { of awards }\end{array}$} & \multicolumn{4}{|c|}{$\begin{array}{l}\text { Number of new } \\
\text { programs/years of funding }\end{array}$} & \multirow{2}{*}{$\begin{array}{l}\text { Number of email } \\
\text { responses (\%) }\end{array}$} \\
\hline & & & & $3 \mathrm{yr}$ & $5 \mathrm{yr}$ & $6 \mathrm{yr}$ & $8 \mathrm{yr}$ & \\
\hline $1999 / 2000$ & $3-y r$ & 31 & 31 & 9 & 0 & 10 & 12 & $22(71)$ \\
\hline 2001 & $3-y r$ & 25 & 25 & 9 & 0 & 0 & 16 & $14(56)$ \\
\hline 2002 & 3-yr plus 3-yr renewal & 19 & 22 & 10 & 0 & 2 & 7 & $9(47)$ \\
\hline 2003 & 3-yr plus 3-yr renewal & 28 & 37 & 19 & 0 & 4 & 5 & $17(61)$ \\
\hline 2004 & 3-yr track I plus 5-yr track II & 15 & 33 & 12 & 0 & 3 & 0 & $7(47)$ \\
\hline 2005 & 3-yr track I plus 5-yr track II & 12 & 20 & 11 & 0 & 0 & 1 & $4(33)$ \\
\hline 2006 & 3-yr track I plus 5-yr track II plus ABR & 17 & 29 & 17 & 0 & 0 & 0 & $7(41)$ \\
\hline 2007 & 5-yr plus 3-yr track II & 15 & 25 & 0 & 15 & 0 & 0 & $7(47)$ \\
\hline 2008 & 5 -yr only & 26 & 26 & 0 & 26 & 0 & 0 & $8(31)$ \\
\hline Total & & 188 & 248 & 87 & 41 & 19 & 41 & $95(51)$ \\
\hline
\end{tabular}

the highest rate in the first cohort (71\%) and the lowest in the 2007-2008 cohort (31\%).

\section{Sustained In-Classroom Programs}

The primary goal of the NSF GK-12 program was to place undergraduate and graduate students in classrooms to enable them to gain teaching and communication skills. The focus of the current study was to assess the number of programs that were able to continue in-classroom programs and to define models that have emerged as sustainable beyond NSF funding. Nineteen universities were able to build programs with sustained in-classroom GK-12 activities post-NSF funding or have commitments in place from internal or external sources of funding to continue once the grant ends. ${ }^{1}$ Based on our survey results and a search of maintained program websites, we have identified at least three different models for continuing to place scientists-in-training in $\mathrm{K}-12$ classrooms: a full-stipend model, a supplemental stipend or "topping-up award" model, and a service-learning model (Table 2). Each of these programs has developed distinct components, but all have retained the primary feature of the GK-12 program of partnering graduate or undergraduate students with $\mathrm{K}-12$

${ }^{1}$ Programs were not counted as sustained if they continued their projects on a no-cost extension of NSF funding for 1-2 yr and were then awarded a new GK-12 grant (at least four universities were in this category). teachers and/or classrooms to achieve the anticipated outcomes of the original GK-12 design.

Eight programs reported that they have been able to sustain or have plans in place to continue the model of supporting fellows with a full stipend, requiring the fellow to spend up to $2 \mathrm{~d} / \mathrm{wk}$ in a $\mathrm{K}-12$ science classroom, although the number of fellows per year has been reduced as NSF support ended. Funding for these programs has come from a variety of sources, including the universities, external grants, the partner school districts, private businesses, and/or foundations. Time commitments for the fellows were generally the same as the original GK-12 grant requirements $(2 \mathrm{~d}$ in a partner classroom). Fellows and teachers were required to attend a summer workshop to plan for the upcoming school year, and several programs planned to continue educationbased course requirements for the fellows. In most programs, partner teachers also received stipends, although at least one university reported that this was the one funding need for which they had not identified a source.

A sustainability model that was proposed at one of the early national GK-12 meetings to fund graduate fellows with topping-up awards or supplemental stipends has been implemented or is planned for implementation on eight campuses. This model retains the basic component of in-classroom time for fellows plus time for planning (i.e., summer workshop). The major differences between this model and the full-stipend model are that the supplemental stipend model includes a reduced stipend and a reduced overall time commitment for

\begin{tabular}{|c|c|c|c|c|c|}
\hline Sustained model & Number of programs & Number of fellows & Time requirement & Stipend & Funding source \\
\hline Full stipend & 8 & $1-4$ & $10 \mathrm{~h}$ to $2 \mathrm{~d} / \mathrm{wk}$ & $\begin{array}{l}\text { University } \\
\text { stipend }\end{array}$ & $\begin{array}{l}\text { University; school district; } \\
\text { foundation }\end{array}$ \\
\hline $\begin{array}{l}\text { Supplemental } \\
\text { stipend }\end{array}$ & 8 & $10-15$ & $1 \mathrm{~d} / \mathrm{wk}$ & $\$ 7-10 \mathrm{~K}$ & $\begin{array}{l}\text { University; external grants; } \\
\text { school district }\end{array}$ \\
\hline $\begin{array}{l}\text { Service-learning } \\
\text { courses }\end{array}$ & 3 & $\begin{array}{l}\text { Based on course } \\
\text { enrollment }\end{array}$ & Semester course & No stipend & $\begin{array}{l}\text { University; external grants; no } \\
\text { cost with Web-based } \\
\text { training; work-study }\end{array}$ \\
\hline
\end{tabular}


the fellows. An example of the supplemental stipend model is now in its 12th year at Vanderbilt. In this program-the Scientist in the Classroom Partnership-graduate students from four partner universities are paid a supplemental stipend of $\$ 7000$ in addition to their normal research or teaching assistantship. The fellows coteach in middle school classrooms with partner teachers for $1 \mathrm{~d} / \mathrm{wk}$. The summer workshop that provides planning time and partnership building has been reduced from the original 4-wk requirement to $2 \mathrm{wk}$, and the academic-year seminar from biweekly to monthly, thus reducing the time demands on the fellows. A variation of this model has been developed at one university at which fellows are provided with a partial stipend for working $2 \mathrm{~d} / \mathrm{wk}$ in a classroom for one semester.

Three universities reported the integration of unique service-learning courses into the undergraduate or graduate curriculum. Each of these programs has developed for-credit courses for students that include a specific number of hours in partner $\mathrm{K}-12$ classrooms presenting hands-on lessons that the fellows have developed as part of the service-learning course. Hours required in the classroom range from several hours per week to $30-50 \mathrm{~h}$ per semester. Funding costs associated with this model are low, with needs ranging from pay for fellows' time (in at least one case covered by federal work-study program funds) to program administration costs. One of these programs has proposed eliminating costs almost completely, as well as offering a Web-based training program for replication at other universities.

Several universities have developed post-NSF models that combine features of two or more sustained models. For example, one university has developed a 2-yr program in which graduate students serve as fellows in year one with full stipends and 2-d commitments, and move to supplemental fellowships with fewer hours per week in the classroom in year two. In addition, at least one university supports both a supplemental stipend model and a service-learning course for fellows.

\section{Other Outcomes of the GK-12 Program}

Although not originally classified as a primary sustainable outcome of the GK-12 program, a number of sites have been able to continue individual components of the GK-12 model, including general outreach activities, intermittent visits to classrooms by fellows, development of on-campus education courses or certificate programs for graduate students, and maintenance of websites containing resources for teachers and classrooms (Table 3). Nine universities specifically reported that they would continue to provide lesson plan resources for teachers through their program websites. Twenty sites were continuing general outreach activities, such as family science nights, science fair judging, and summer programs for students and/or teachers that would involve university faculty and graduate students. Six programs reported that they would continue to offer graduate education courses developed during the GK-12 program that focused on enhancing graduate teaching skills, as well as an understanding of the needs and challenges of the K-12STEM community. These courses formed the basis for new graduate education certificate programs at several universities that would enhance the fellows' curriculum vitae in support of their career development.
Table 3. Categories of GK-12 program outcomes

\begin{tabular}{lc}
\hline Category & $\begin{array}{c}\text { Number of } \\
\text { programs }^{\mathrm{a}}\end{array}$ \\
\hline $\begin{array}{l}\text { In-classroom } \\
\text { General outreach }\end{array}$ & 19 \\
Maintenance of websites with teacher resources & 20 \\
$\begin{array}{l}\text { Education courses and certificate programs for } \\
\text { graduate students }\end{array}$ & 6 \\
Total & 54 \\
\hline aprograms were counted in only one category; the numbers indicated \\
in the table represent the primary category mentioned in the email \\
responses.
\end{tabular}

Although not included as a sustained category in this study, it should be noted that several universities reported that centers had been established at their universities, either as a direct result of receiving funding to implement a GK-12 program or to provide oversight for the GK-12 program activities. The Vanderbilt Office of Science Outreach, established in 2000, was elevated to center status in 2003, and the University of Kentucky created a formal math and science outreach institute - the Partnership Institute for Math and Science Reform. The Center for Mathematics and Science Education at the University of Mississippi has continued many of the campus GK-12 outreach activities, and Northeastern University reported the establishment of the Center for STEM Education. The STOMP program has also led to the development of a center at Tufts, with the added feature of forming a network of participating universities with similar GK-12 programs.

\section{Reasons for Lack of Sustainability}

Responses from GK-12 PIs indicated a variety of reasons why the in-classroom component of their programs could not be sustained (shown in Table 4). First, most of the programs that were able to sustain an in-classroom model were funded for 6 or 8 yr (Figure 1). Of the $873-y r$ programs, only three were identified that sustained in-classroom activities, while eight 6-yr programs and eight 8-yr programs were able to continue these in-classroom models. One PI commented that "we really needed another two-three years of NSF funding" to achieve sustainability. Another PI stated that the program could not be sustained on their campus due to the low number of available STEM graduate students. Significantly, three universities stated that the program ended due to lack of university support, suggesting that buy-in at the front end of the

Table 4. Reasons for lack of sustainability

\begin{tabular}{lc}
\hline Reason & $\begin{array}{c}\text { Number of } \\
\text { programs }\end{array}$ \\
\hline Lack of funding & 18 \\
No sustainability plan built into the grant & 13 \\
Too few years of funding & 5 \\
PI retired or left the university & 3 \\
University did not value the program & 3 \\
Changes in school district or university & 2 \\
$\quad$ administration & 1 \\
\hline
\end{tabular}




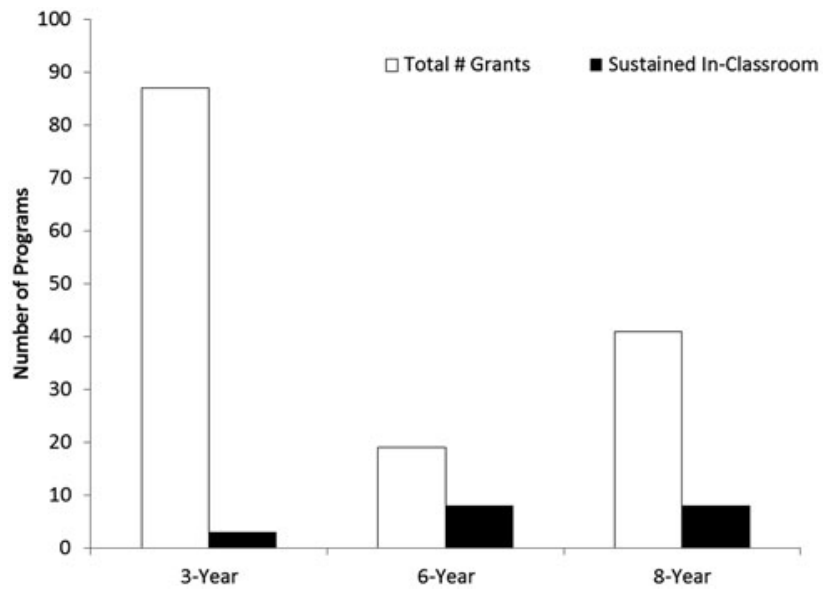

Figure 1. Number of sustained GK-12 programs compared with total programs funded. A total of 188 GK-12 grants were awarded between 1999 and 2008. During this time period, grants were funded for 3 to 8 yr. The breakdown for the total number of grants funded for 3, 6, and $8 \mathrm{yr}$ is shown by the open bars. Based on results from the current study, 19 of these grants were classified as sustained models, in which graduate students taught in K-12 classrooms in partnership with teachers. The number of sustained programs for the 3-, 6-, and 8 -yr awards are shown in the filled bars ( 3 of 87 3-yr grants; 4 of 19 6-yr grants; and 4 of 41 8-yr awards). Data are not presented for 5-yr awards, since these programs have only been in place since 2007 and have not yet developed sustainability plans for post-NSF funding.

programs was essential for their continuation. Three universities mentioned that the PI had left the university or retired, and the program did not continue beyond their departure.

One requirement of the GK-12 grant applicants was to include a well-developed plan for sustainability in their grant proposal. Thirteen PIs specifically stated that they had yet to define a plan for continuing their program. In several instances, talks were planned or ongoing with university administrators, but no progress had yet been made. Further highlighting the lack of preaward development of a sustainability plan was the request by 18 PIs to share the findings of this study with respect to scalable and replicable models. Several PIs responded that they would be interested in seeing how other programs were able to sustain their goals beyond NSF funding.

By far the most common response to the question of sustainability was the lack of funding. At least 18 programs cited the lack of financial resources as the reason for the end to their program. Programs that were successful in sustaining their projects used a variety of funding strategies (Table 5). As stated by one PI, "We will be sustained-but the barriers for others is obvious-money. This is an expensive program. Unless you get external funding, you can't keep it going." Most of the universities reported that their programs were funded primarily through a combination of university sources, including university central administration (provost and deans), departments, or individual faculty members. At least four universities that have since ended their programs indicated that they had attempted to get state funding but did not succeed or are still in the process of negotiations with the state government. Seven universities folded the inclassroom model into external grants from the NSF (Math and Science Partnership [MSP], Innovation through Institutional
Table 5. Strategies for funding sustained GK-12 programs

\begin{tabular}{|c|c|}
\hline Funding source & $\begin{array}{c}\text { Number of } \\
\text { programs }\end{array}$ \\
\hline \multicolumn{2}{|l|}{ University } \\
\hline Provost/college deans & 16 \\
\hline Academic department & 5 \\
\hline Individual faculty & 1 \\
\hline Campus center/institute & 4 \\
\hline Private foundations, local organizations, industry & 8 \\
\hline Non-GK-12 external grants ${ }^{\mathrm{a}}$ & 7 \\
\hline Local school system & 3 \\
\hline State $^{\mathrm{b}}$ & 4 \\
\hline
\end{tabular}

Integration [I3], Innovative Technology Experiences for Students and Teachers [ITEST], and Integrative Graduate Education and Research Traineeship Program [IGERT] grants, Research Experiences for Undergraduates [REU] supplements, and broader impacts), the NIH (Science Education Partnership Award [SEPA] program), and the Howard Hughes Medical Institute (HHMI). One PI stated that they were specifically targeting broader-impact sections on NSF grants, since they had convinced faculty that the GK-12 in-classroom program would strengthen their applications. Three universities were successful in securing support from their partner school district. For example, Vanderbilt's program has received the majority of funding from the school district for the past $3 \mathrm{yr}$. At least eight universities have turned to local businesses, industries, and foundations for support. Several PIs responded with very detailed plans for sustaining their in-classroom programs, underscoring the complex strategies that many universities are using to cover costs. In addition to the support from the local school district, Vanderbilt has received funding from partner universities, local foundations, individual schools, and external grants.

\section{DISCUSSION}

The NSF-funded GK-12 program has had a significant impact on all participants, including graduate students, classroom teachers, and K-12 students, and has created and strengthened university and $\mathrm{K}-12$ partnerships. More than 10,000 graduate students have worked in 5000 schools with 11,000 teachers and 600,000 students, and several hundred university-school system partnerships were established to host these programs (Mervis, 2011). There is compelling evidence that many of the expected outcomes of the funded programs have been achieved: fellows learned to teach and to better communicate their scientific research to the public and had a chance to give back to their communities; teachers had scientist partners who led laboratory activities, brought real-world science into the classroom, acted as role models for students, and at the very least provided an extra pair of hands; students became more enthusiastic about science and STEM careers and in a few cases, showed improved achievement (Gamse et al., 2010). However, the important legacy of the GK-12 
program is in danger of disappearing now that the program is no longer funded (Boone and Marsteller, 2011; Mervis, 2011; Raju and Clayson, 2011), and many programs have failed to build in viable sustainability plans for new revenue sources or strategies to incorporate activities into either the university or the partner school district academic structures. A significant percentage of GK-12 programs have simply shut down, ending both graduate student involvement in $\mathrm{K}-12$ education and productive university-school district partnerships. The positive news is that a cadre of passionate PIs has been successful in sustaining this GK-12 legacy, and they have provided important models and strategies for moving beyond GK-12 funding.

At the core of the GK-12 program is the partnering of graduate students with $\mathrm{K}-12$ teachers to enhance the learning and teaching of STEM. Numerous reports from national policy organizations, as well as studies in the literature, have emphasized the importance of connecting the $\mathrm{K}-12$ and higher-education communities to advance STEM teaching and learning (Dolan and Tanner, 2005; Tomanek, 2005; Foster et al., 2010). Bruce Alberts, former president of the National Academy of Sciences, stated that "Scientists and engineers working in partnership with local teachers represent an essential new force that will be required for effective science education reform" (Alberts, 1994). GK-12 program creator and former NSF director Rita Colwell underscored the need for partnering scientists with $\mathrm{K}-12$ classrooms: "There is no group of people who should feel more responsible for science and math education in this nation than our scientists and scientists-to-be" (Colwell, 1998). The recent report to the president from the Council of Advisors on Science and Technology stated that "a great many scientists and engineers would be willing to contribute to improving STEM education, both in school and out of school, if an efficient and effective way for them to do so could be put in place" (President's Council of Advisors on Science and Technology, 2010). Although many universities have outreach programs that support volunteer scientists entering $\mathrm{K}-12$ classrooms, in-depth partnerships between teachers and scientists must be developed and nurtured to adequately prepare these scientists to contribute substantively to STEM learning (Tanner et al., 2003). The GK-12 program established in 1999 provides exactly the type of mutual partnership that many have called for: a program to bolster the communication and teaching skills of our scientists in training, while enhancing the science content and confidence of classroom teachers and the excitement for scientific learning in $\mathrm{K}-12$ students.

In the current study, programs funded during the period 1999-2008 were examined to determine the outcomes and sustainability of their GK-12 projects. Results show that the sustained GK-12 models could be classified into two categories ranging from minimal to no involvement of graduate students to weekly in-classroom, coteaching partnerships with $\mathrm{K}-12$ teachers. Features of each of these models are presented in Table 6 with a discussion outlining the impacts, costs, and potential for replication.

General Outreach Programs. A number of universities have established centers on their campuses to coordinate outreach programs that provide opportunities for students to work with the local $\mathrm{K}-12$ school district. Outreach programs do raise awareness on the campus for the need to connect higher- education and $\mathrm{K}-12$ schools, but these projects are often limited in scope, with little time spent by the scientist in the classroom, effectively eliminating the establishment of a true partnership between scientist and teacher. Scientists who volunteer for outreach activities view these as ancillary to their primary university responsibilities, and report that lack of flexibility in scheduling, time constraints, and the absence of university value placed on this volunteer work detracts from significant time devoted to work with schools (Pelaez and Gonzalez, 2002).

Service-Learning Model. A second model that has been implemented is the integration of GK-12-like activities into service-learning courses. This model combines community service and experiential learning and has the potential to be easily adopted by universities to replicate and/or sustain a GK-12 in-classroom model. A number of STEM departments at universities have recognized the potential for service learning to provide undergraduate, graduate, and professional students with opportunities to gain communication, teamwork, and leadership skills; an understanding of diversity; an appreciation of the societal impacts; and an ability to apply these skills in their careers (Eyler et al., 2001). As suggested by Gravel and colleagues, the benefits of the GK12 model program should align with the benefits of service learning, as they are so closely related (Gravel et al., 2005). One university reported the adaptation of their GK-12 program into a service-learning curriculum to provide graduate students with an opportunity to connect their research to effective K-12 outreach (Harbor, 2011). Based on evaluation of outcomes, this low-cost program appears to be achieving many of the benefits of the GK-12 program; however, the model is limited by the moderate-to-low overall impact on program participants. In several programs, fellows' coteaching in the classroom is limited to hours per month rather than $1-2 \mathrm{~d} / \mathrm{wk}$, diminishing the formation of a meaningful and effective teacher-fellow partnership. In addition, the fellows have a reduced connection to the students, thus lowering the fellows' impact to one of increasing the exposure of students to science activities. This is perhaps the most important component of the GK-12 program, and one that will be lost as universities shift to volunteer or lower time commitment on the part of scientists in classrooms. Many universities have partnership programs that encourage scientists to visit classrooms to present a lesson or lecture on a particular topic. The true impact of the GK-12 program is that these scientists actually spend two full days in classrooms-not simply dropping in on an occasional basis. As emphasized in the Rand Corporation GK-12 evaluation, deeper partnerships are needed to effect true change, rather than a "drop in the reform bucket" (Williams, 2002).

Original Full-Stipend GK-12 Model. The full-stipend model, based on the original GK-12 program, has the potential for the greatest impact on graduate student and teacher professional development, as well as student learning. However, there are several challenges that reduce the model's potential for sustainability. First, the funding required is the highest of the three categories. Although some universities reported that they have been able to sustain this type of program, each campus has had to reduce the number of fellows to 
Table 6. Potential impacts of sustained in-classroom programs compared with general outreach activities

\begin{tabular}{|c|c|c|c|c|}
\hline & $\begin{array}{l}\text { Supplemental stipend } \\
\text { fellowships }\end{array}$ & Full-stipend fellowships & $\begin{array}{l}\text { Service-learning-based } \\
\text { courses }\end{array}$ & General outreach programs \\
\hline Structure & $\begin{array}{l}\text { Fellows coteach } 1 \mathrm{~d} / \text { wk in a } \\
\text { K-12 STEM classroom in } \\
\text { partnership with a } \\
\text { teacher. }\end{array}$ & $\begin{array}{l}\text { Fellows coteach } 2 \mathrm{~d} / \text { wk in a } \\
\mathrm{K}-12 \text { STEM classroom in } \\
\text { partnership with a } \\
\text { teacher, as per the } \\
\text { original GK-12 model. }\end{array}$ & $\begin{array}{l}\text { Fellows take courses } \\
\text { developed by university } \\
\text { faculty that incorporate } \\
\text { development and } \\
\text { delivery of science } \\
\text { lessons in K-12 } \\
\text { classrooms. }\end{array}$ & $\begin{array}{l}\text { General outreach includes } \\
\text { inexpensive programs } \\
\text { that rely on university } \\
\text { faculty or student } \\
\text { volunteers leading } \\
\text { science activities or } \\
\text { developing curricula for } \\
\text { K-12. }\end{array}$ \\
\hline \multirow[t]{2}{*}{$\begin{array}{l}\text { Funding } \\
\text { requirements }\end{array}$} & $\begin{array}{l}\text { Costs included topping-up } \\
\text { awards or partial } \\
\text { stipends }(\$ 5 \mathrm{~K}-10 \mathrm{~K}) \text { for } \\
\text { fellows, stipends for } \\
\text { teachers, salary for } \\
\text { coordinator. }\end{array}$ & $\begin{array}{l}\text { Costs include full stipends } \\
\text { for fellows, stipends for } \\
\text { teachers, salary for } \\
\text { coordinator. }\end{array}$ & $\begin{array}{l}\text { Costs involve support of the } \\
\text { faculty member to teach } \\
\text { the course and materials } \\
\text { for the classroom } \\
\text { supplies. }\end{array}$ & $\begin{array}{l}\text { Volunteer scientists and } \\
\text { teachers require no cost. } \\
\text { Coordinator may be } \\
\text { faculty or staff member } \\
\text { whose salary is paid by } \\
\text { the university or a grant } \\
\text { source. }\end{array}$ \\
\hline & $\begin{array}{l}\text { Estimated annual cost for } 10 \\
\text { fellows: } \$ 120,000\end{array}$ & $\begin{array}{l}\text { Estimated annual cost for } 10 \\
\text { fellows: } \$ 320,000\end{array}$ & Minimal cost & Minimal cost \\
\hline Impact potential & $\begin{array}{l}\text { High: Fellows working in } \\
\text { classrooms for } 1 \mathrm{~d} / \mathrm{wk} \\
\text { have a high impact on all } \\
\text { participants. The limited } \\
\text { costs per fellow allows } \\
\text { for a significant number } \\
\text { of fellows per year } \\
(10-15) .\end{array}$ & $\begin{array}{l}\text { Medium to high: Fellows } \\
\text { working in classrooms } \\
\text { for } 2 \mathrm{~d} / \mathrm{wk} \text { have a } \\
\text { significant impact on all } \\
\text { participants. The small } \\
\text { number of fellows limits } \\
\text { the impact to a few } \\
\text { classrooms. }\end{array}$ & $\begin{array}{l}\text { Low to medium: There is a } \\
\text { high impact on the } \\
\text { fellow, but limited } \\
\text { impact on teachers, since } \\
\text { a true partnership with a } \\
\text { scientist is not } \\
\text { developed. Students } \\
\text { benefit from the } \\
\text { exposure to scientists } \\
\text { and hands-on lessons. }\end{array}$ & $\begin{array}{l}\text { Low: The programs raise } \\
\text { university awareness of } \\
\text { the needs of K-12 STEM } \\
\text { education and students } \\
\text { are inspired by the } \\
\text { scientists. A lasting } \\
\text { impact on learning may } \\
\text { be difficult to measure. }\end{array}$ \\
\hline $\begin{array}{l}\text { Potential for } \\
\text { sustainability }\end{array}$ & $\begin{array}{l}\text { Medium to high: With } \\
\text { cost-sharing among } \\
\text { partners, this model may } \\
\text { be the best adaptation of } \\
\text { the GK-12 program that } \\
\text { will continue the benefits } \\
\text { for all partners at a } \\
\text { reasonable cost. }\end{array}$ & $\begin{array}{l}\text { Low: The high cost for a } \\
\text { minimal number of } \\
\text { fellows requires securing } \\
\text { a significant level of } \\
\text { funding for the program. }\end{array}$ & $\begin{array}{l}\text { High: Service learning is a } \\
\text { growing area of } \\
\text { university education, } \\
\text { and there is a mutual } \\
\text { benefit in combining } \\
\text { science outreach and } \\
\text { service learning. }\end{array}$ & $\begin{array}{l}\text { Medium to high: Volunteer } \\
\text { movements are growing } \\
\text { on campuses, but this is } \\
\text { not often an option for } \\
\text { graduate students. } \\
\text { Teachers may view } \\
\text { occasional visits as a } \\
\text { distraction for students. }\end{array}$ \\
\hline
\end{tabular}

significantly fewer than the original 10-12 supported through GK-12 funding; in most cases, one or two fellows are supported through this program model. In addition, most programs have reduced the stipend from the GK-12 level of funding $(\$ 30,000)$ to one that more closely aligns with university research or teaching assistantships. All of the programs that have full-stipend models in place indicated that it was a constant challenge to identify funding, and all are currently using multiple sources, such as university funds, support from outside foundations and business partners, and/or grant funds from federal agencies. An additional challenge to implementing this model is the time demand on the fellows. Although some faculty realize the benefits of the teaching experience for the fellows, many PIs have stated that $2 \mathrm{~d} / \mathrm{wk}$ takes too much time away from the fellows' research (Thompson et al., 2002a; Gamse et al., 2010). In addition to the required time in the classroom, fellows in this model also attend a summer workshop requiring a time commitment of $2-4 \mathrm{wk}$, and additional time during the academic year for educational courses and/or seminars.

Supplemental Stipend Model. The supplement stipend model has several features that suggest that this could be a model that is replicable and affordable, with high impact and relatively low cost. This model emerged from an idea originally suggested early in the GK-12 program by a group of PIs interested in sustaining their in-classroom programs. Fellows work with partner teachers in a classroom for $1 \mathrm{~d} / \mathrm{wk}$, attend a 2-wk workshop in the summer to develop the partnership and plan for the upcoming academic year, and in some programs, take education courses or seminars. Fellows are provided a supplement or topping-up award in addition to their teaching or research assistantship. The impact of this program is significant, with benefits for all partners. As evidenced in the Vanderbilt program, fellows are able to establish effective and meaningful relationships with both teachers and students; fellows gain important teaching and communication skills; teachers receive much-needed support in the classroom, while gaining science content knowledge; and students' interest in and enthusiasm for, as well as achievement in STEM, is enhanced (Ufnar et al., unpublished data). Costs are lower than for the full-stipend model, but still require focused efforts to maintain needed financial support. The Vanderbilt program costs approximately $\$ 120,000$ per year for 10 fellows, 10 teachers, and one full-time coordinator. Importantly, the partner school district is not only the major 
funder, but has integrated this model into a long-range plan for sustaining scientists in classrooms as important resources in support of teachers. A potential challenge in this model is the time commitment for fellows, who still commit $1 \mathrm{~d} / \mathrm{wk}$ to working in their partner classroom, taking time away from their research. However, faculty who support the Vanderbilt program have realized that it does not increase the time to graduation, that fellows actually become more organized and develop better time-management skills, and that fellows gain important teaching and mentoring skills, a finding that has been substantiated by reports from other GK-12 programs (Thompson et al., 2002a; Trautmann, 2008). As evidence of the support from the partner universities for this program, the number of participating fellows has steadily increased over the past several years, with 15 fellows currently working in one elementary, four middle, and two high schools. As one PI of a full-stipend program in this study stated, he would rather have 15 fellows in a supplemental stipend model than two to three fellows supported by full stipends.

Overall, the GK-12 program has successfully achieved many of the goals stated in the annual NSF program announcements, with thousands of students, fellows, and teachers gaining important knowledge and skills through hundreds of individual university-school district partnerships. However, as shown in this study, many of the individual programs could not be sustained, due to a variety of reasons, including the lack of viable sustainability plans to support the high costs required for the in-classroom partnerships. Based on these results and observations, several recommendations have emerged from this study to ensure that the benefits and outcomes from the GK-12 program are not lost. First, a program could be established by the NSF or other funding agencies that would provide small seed grants to universities interested in establishing a GK-12-like program. These universities would be required to create a formal collaboration with a sustained GK-12 program site to develop the best program model for that university. The PI from the sustained site could be awarded a small stipend to work with the new university PI and school district to implement the program and ensure sustainability. Studies have shown that unless partnerships developed between $\mathrm{K}-12$ and higher-education institutions have support from groups with an intimate working knowledge of both communities, these partnerships will fail, and benefits to the partners will be limited (Tanner et al., 2003). Therefore, it is imperative that a PI from an institution with a strong school system partnership and sustained in-classroom program be included in the planning and implementation phases when this type of program is started at a new institution.

A second recommendation is the development of a supplemental program that would allow interested graduate students an avenue for gaining valuable teaching experience through a sustained GK-12-like model. The proposed Teaching Experiences for Fellows (TEF) program, based on the sustainable supplemental stipend fellowship model shown in this study (Table 6), would cover a partial stipend for a graduate student to participate in teaching $1 \mathrm{~d} / \mathrm{wk}$. This supplement program would be similar in scope to the REU and Research Experience for Teachers (RET) programs currently funded by the NSF. In both of these ongoing programs, undergraduates and $\mathrm{K}-12$ teachers are involved in meaningful ways in the research program of the participating university.
In a similar manner, the TEF fellow who already is participating in STEM research would extend this knowledge and expertise to the $\mathrm{K}-12$ classroom. As in the RET program, the TEF fellows would "help build long-term collaborative partnerships between K-12 STEM teachers. . and the NSF university research community" by involving STEM graduate students in translating "their research experiences and...knowledge into classroom activities" (NSF, 2011a,b). The supplement application would be submitted by both the student and the research mentor to indicate commitment to the program.

A third option would be to recommend that the NSF encourage the incorporation of supplemental graduate student stipends into broader-impact statements. These supplements would provide teaching experiences for graduate students at 4 -yr institutions with sustained GK-12 programs. The results from the current study indicate that several PIs were successful in integrating GK-12 supplements for graduate students into NSF broader-impact statements in sustaining the program. This type of supplement can be described in the NSF research funding announcements as a recommended addition to the planned broader impacts. The NSF would specifically state in the request for proposal broader-impact description that one example of impacting a wider audience by connecting university research with the $\mathrm{K}-12$ community and helping to train the next generation of scientists is the GK-12 model funded by the NSF from 1999 to 2010.

Presently, there is a push from all areas of society to bolster STEM education in this country. Studies have shown that interventions such as a sustained GK-12 program have positive impacts on scientists, students, and teachers in the form of increased understanding of science concepts by teachers and students, increased excitement about science, and increased ability to communicate science to the public on the part of the participating scientists (Stamp and $\mathrm{O}^{\prime}$ Brien, 2005; Trautmann and Krasny, 2006; Brawley et al., 2008; Gamse et al., 2010). Unfortunately, many of the GK-12 programs have ended, due to the high cost of the program, lack of funding opportunities, lack of a clear sustainability plan, lack of support by the university and partner school system, a substantial time commitment for fellows, and the lack of integration of the program into the academic structure of both the university and partner school system. Modified GK-12-like programs, such as those proposed in the current study, have the opportunity to enhance the delivery and understanding of STEM education by our graduate scientists and $\mathrm{K}-12$ teachers and students, if supported by granting institutions. Rita Colwell, the creator of the GK-12 program, is quoted as saying that this program "...is unique in using them [the fellows] to bring science into the $\mathrm{K}-12$ class at the same time it supports their graduate education. And given the poor state of STEM education in the schools, this is vitally important" (Mervis, 2011).

\section{REFERENCES}

Alberts B (1994). Scientists have important roles, responsibilities in future of science education. Forum on Education newsletter, November. www.aps.org/units/fed/newsletters/nov94/alberts.html (accessed 5 June 2011).

American Association for the Advancement of Science (2011). NSF GK-12 Project Locator. www.gk12.org/project-locator (accessed 6 March 2009). 
American Institute of Physics (2011). FY 2012 STEM Education Budget Request. www.aip.org/fyi/2011/019.html (accessed 10 July 2011).

Bledsoe KE, Shieh R, Park Y-S, Gummer E (2004). Role perceptions and role dynamics between graduate scientists and $\mathrm{K}-12$ teachers in a school-university outreach project: understudied constructs. J Higher Educ Outreach Engagement 9, 107-121.

Boone R, Marsteller P (2011). Avoiding a setback to STEM. Science $333,267$.

Brawley SH, Pusey J, Cole BJW, Gott LE, Norton SA (2008). A revolutionary model to improve science education, teachers, and scientists. Maine Policy Review 17, 68.

Colwell R (1998). Address to the DC Science Writers Association. National Science Foundation, Office of Legislative and Public Affairs. www.nsf.gov/news/speeches/colwell/rc80908.htm (accessed 6 February 2011).

Cormas PC, Barufaldi JP (2011). The effective research-based characteristics of professional development of the National Science Foundation's GK-12 program. J Sci Teach Educ 22, 255-272.

Dolan E, Tanner K (2005). Effective partnerships between K-12 and higher education. Cell Biol Educ 4, 35-37.

Eyler JS, Giles DE, Stenson CM, Gray CJ (2001). At a glance: what we know about the effects of service-learning on college students, faculty, institutions, and communities, 1993-2000. www.servicelearning.org/filemanager/download4192_AtAGlance .pdf (accessed 15 September 2011).

Foster KM, Bergin KB, McKenna AF, Millard DL, Perez LC, Prival JT, Rainey DY, Sevian HM, VanderPutten EA, Hamos JE (2010). Partnerships for STEM education. Science 329, 906-907.

Gamse B, Smith WC, Parsad A, Dreier J, Neishi K, Carney J, Caswell L, Breaux E, McCall T, Spader J (2010). Evaluation of the National Science Foundation's GK-12 program. Cambridge, MA: Abt Associates.

Gravel B, Cunningham C, Knight M, Faux R (2005). Learning through teaching: a longitudinal study on the effects of GK-12 programs on teaching fellows. Paper presented at the American Society for Engineering Education Annual Conference and Exposition, Portland, OR.

Harbor J (2011). A locally-sustained GK-12 partnership provides an effective way for diverse graduate students to reach K-12 students and support schools. Paper presented at the Geological Society of America Annual Meeting, Minneapolis, MN, October 9-12, 2011.

Lundmark C (2004). Inquiry in K-12 classrooms: graduate students and teachers team up. BioScience 54, 295.

Mervis J (1999). Grad students head to class as new NSF teaching fellows. Science 286, 895.

Mervis J (2011). Outreach greets NSF decision to end STEM fellows program. Science 331, 11.

National Science Foundation (NSF) (2009). STEM Fellows in K-12 Education (GK-12). Program Solicitation. www.nsf.gov/pubs / 2009/nsf09549/nsf09549.htm (accessed 6 March 2011).
NSF (2011a). Research Experiences for Teachers. www.nsf.gov/ funding/pgm_summ.jsp?pims_id=5736 (accessed 9 June 2011).

NSF (2011b). Research Experiences for Undergraduates. www .nsf.gov/funding/pgm_summ.jsp?pims_id $=5517 \&$ from $=$ fund (accessed 9 June 2011).

Pelaez NJ, Gonzalez BL (2002). Sharing science: characteristics of effective scientist-teacher interactions. Adv Physiol Educ 26, 158167.

President's Council of Advisors on Science and Technology (2010). Prepare and Inspire: K-12 Education in Science, Technology, Engineering, and Math (STEM) for America's Future. www.whitehouse .gov/sites/default/files/microsites/ostp/pcast-stemed-report.pdf (accessed 12 January 2011).

Raju RK, Clayson A (2011). NSF GK12 program must be saved: what you can do to help. J STEM Educ 12, 6-8.

Smith R, Hollebrands K, Parry E, Bottomley L, Smith A, Albers L (2009). Effects of a GK-12 program on students' achievement in and beliefs about mathematics. Proceedings of the American Society for Engineering Education Annual Conference, 1266.

Spillane SA (2004). Sharing strengths: educational partnerships that make a difference. Paper presented at the American Education Research Association Annual Meeting. San Diego, CA, April 12-16, 2004.

Stamp N, O'Brien T (2005). GK-12 partnership: a model to advance change in science education. BioScience 55, 70-77.

Tanner KD, Chatman L, Allen D (2003). Approaches to biology teaching and learning: science teaching and learning across the school-university divide-cultivating conversations through scientist-teacher partnerships. Cell Biol Educ 2, 195-201.

Thompson S, Collins A, Metzgar V, Joesten M, Shepherd V (2002a). Exploring graduate-level scientists' participation in a sustained K-12 teaching collaboration. School Sci Math 102, 254-265.

Thompson SL, Metzgar V, Collins A, Joesten MD, Shepherd VL (2002b). Examining the influence of a graduate teaching fellows program on teachers in grades 7-12. Paper presented at the Annual International Conference of the Association for the Education of Teachers in Science, Charlotte, NC, January 10-13, 2002.

Tomanek D (2005). Effective partnerships between $\mathrm{K}-12$ and higher education. Cell Biol Educ 4, 28-37.

Trautmann NM (2008). Learning to teach: alternatives to trial by fire. Change 40, 40-45.

Trautmann NM, Krasny ME (2006). Integrating teaching and research: a new model for graduate education? BioScience 56, 159165.

Williams V (2002). Merging University Students into K-12 Science Education Reform, Washington, DC: RAND Corporation.

Williamson K, Ndahi H, Waters S, Nelson L (2005). Facing the realities of "high-stakes" testing while keeping science and engineering outreach alive. Proceedings of the American Society for Engineering Education Annual Conference, 6333-6340. 